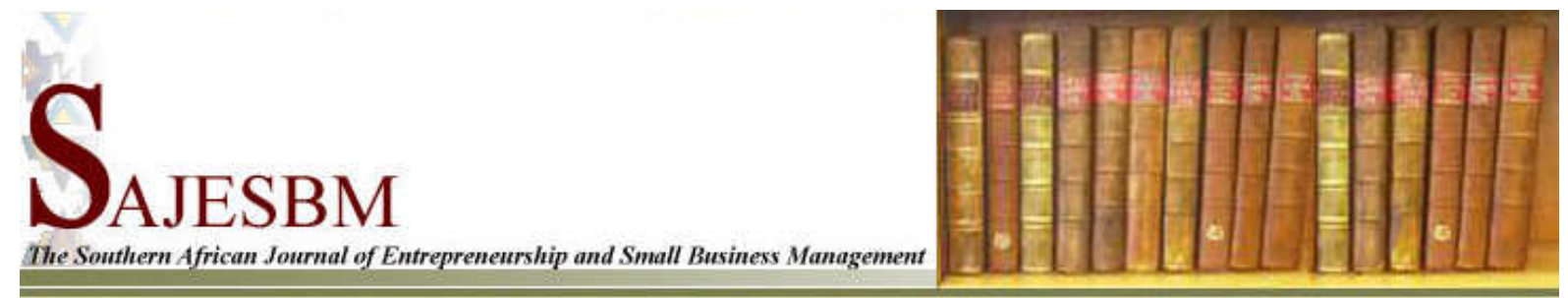

www.sajesbm.com

\title{
Critical Success Factors of Indian Entrepreneurs
}

\author{
Alex ANTONITES* \\ Department of Business Management \\ University of Pretoria; \\ Thiloshini GOVINDASAMY \\ Gordon Institute of Business Sciences (Gibs) \\ University of Pretoria.
}

*Corresponding author

Email: alex1@up.ac.za;

Tel. +2712420 3119 .

Postal Address: Dept Business Management,

University of Pretoria

Pretoria 0002

\begin{abstract}
This research seeks to explore the critical success factors that influence the success of Indian small business owners in the largest metropolitan area in South Africa. To achieve this, the objective of the study was to confirm whether there are significant differences between a successful and less successful group of business owners in terms of general management skills, personal characteristics, and entrepreneurial orientation and financing of the business. Through analysing secondary evidence and empirical results it was possible to facilitate a better understanding of how Indian entrepreneurs operating in small and medium enterprises sustain success, thus contributing to the body of knowledge relating to entrepreneurship development in the domain of entrepreneurship. From the literature it became clear that cultural dimensions have an impact on the entrepreneurial process. The arrival of Indians in South Africa has contributed to a unique Indian culture. The characteristics that describe ethnic entrepreneurs and success factors attributed to their success are described. Small and medium enterprises (SMEs) are crucial for the development of any country as they offer benefits of economic growth and employment generation. The success factors to sustain SMEs are also described. The findings of the study indicate that there are no significant differences between the comparable groups in relation to management skills and finance factors. There are, however, significant differences relating to personal factors, such as the level of education, family support and experience. Finally, an important learning is that the Indian entrepreneurs in this study are similar to ethnic entrepreneurs reviewed in literature. The study was conducted in Tshwane, the largest metropolitan area in South Africa, and amongst the largest in the world.
\end{abstract}


Keywords: Culture, ethnic entrepreneurship, Indian entrepreneurship, critical success factors, small and medium enterprises (SMEs), successful SMEs.

\section{INTRODUCTION}

Entrepreneurs are a unique group of people as they assume risk, manage the business' operations, reap the rewards of their success and bear the consequences of their failure (Henderson 2002). The author typifies two kinds of entrepreneurs, in reference to lifestyle and growth. "Lifestyle entrepreneurs" start business ventures to provide a family income or support a desired lifestyle, while "high-growth entrepreneurs" are motivated to start and develop larger, highly visible, and more valuable ventures.

These entrepreneurs are focused on obtaining the resources necessary to fuel growth. Wickham (2006) depicts the growth-orientated entrepreneur as having high levels of innovation and specific growth orientated strategic objectives.

Ucbasaran, Wright, and Westhead (2003), distinguish between the "habitual starter" and the "habitual acquirer" entrepreneur. In their longitudinal study on entrepreneur starters and acquirers, the authors conveyed that the "habitual starter entrepreneur" was found to consider enhanced reputation as a key asset resulting from prior ownership experience and was likely to use the increased legitimacy to gain resources to address the hurdles in the formation of subsequent ventures. The "habitual acquirer entrepreneur" was more likely to report that their business networks had been enhanced by prior business ownership because they belong to more networks by virtue of their previous experience in established organisations.

Minniti and Lévesque (2010) describe two types of entrepreneurs - "research-based entrepreneurs" who incur research and development costs and commercialize technological discoveries, and "imitative entrepreneurs" who increase product availability and competition by replicating technologies developed elsewhere. The authors conclude that the presence of either type of entrepreneurship has a positive effect on the growth pattern of an economy. The relative distribution of entrepreneurs across the two categories does not influence the growth rate; what matters is that a country has a relatively high absolute number of at least one type of entrepreneur.

The 2005 Global Entrepreneurial Monitor Report on South Africa (von Broembsen, Wood, and Herrington 2005) concluded that Indians and Whites are more likely to start a business than Blacks or Coloureds (in a cultural categorisation context). The report indicated that Indian and White businesses are more likely to survive the incubation period and employ more people. The report indicates that about 3.7 percent of White owner-managed businesses create over 20 jobs while 7 percent of Indian owner-managers are responsible for the same number of jobs. This implies that Indian entrepreneurs create more jobs than other racial groups in South Africa (von Broembsen et al. 2005). The 2008 Global Entrepreneurial Monitor Report on South Africa concluded that businesses started by Indians and Whites were more likely to mature into new firms than any other racial group (Herrington, Kew, and Kew 2008).

Ethnic entrepreneurs are united by a set of socio-cultural connections and regular patterns of interaction among people sharing a common national background or migration experiences (Waldinger, Aldrich, and Ward 1990). The Indian entrepreneur in South Africa can be described as an "ethnic entrepreneur". Ethnic enclave theory sees an ethnic enterprise as a self-generating process, whereby the ethnic enterprise can act as a training system for new entrepreneurs through employment in existing enterprises, generating network linkages, thus generating a basis for informal communication, market opportunities and providing community role models (Aldrich, Zimmer, and McEvoy 1989; Waldinger 1989, cited by 
Chaudhry and Crick 2008). Chaudhry and Crick (2008), in their study of leading practices of Asian entrepreneurs in the United Kingdom, found that entrepreneurs took advantage of niche market opportunities and with hard work and talent were able to take their businesses into the mainstream market and professionalize their businesses. Research has also stereotyped Asian entrepreneurs as being reliant on family support to finance and to help run their businesses.

The rationale for undertaking this study is to explore the factors that successful Indian entrepreneurs attribute to their success as well as to evaluate how these factors compare with less successful Indian entrepreneurs. Based on this understanding, there are learning knowledge and insights for entrepreneurship training and development. The study aims to contribute to the growing body of knowledge that attempts to profile entrepreneurs of different cultural backgrounds.

\section{LITERATURE REVIEW}

In the 1870s anthropologist Edward Tylor defined culture as "that complex whole which includes knowledge, belief, art, morals, law, customs and other capabilities acquired by man" (Hill, 1997:67). Hofstede (2001:9) broadens this construct and defines it "as the collective programming of the mind that distinguishes the members of one group or category from another" (Chrisma, Chua, and Steier 2002, 114).

Granato, Inglehart, and Leblang (1996) refer to "culture" as a system of basic common values that help shape the behaviour of the people in a given society. Hill $(1997,67)$ views culture "as a system of values and norms that are shared among a group of people and that when taken together constitute a design for living." The author elaborates by defining values as the abstract ideas about what a group believes to be good, right and desirable; norms as the social rules and guidelines that prescribe appropriate behaviour, and society as the group of people who share a common set of values and norms.

Hofstede (1998) defines "values" as a broad tendency to prefer a certain state of affairs over others with the belief that values are determined early in life. Hill (1997) states that the values and norms of culture do not emerge from nowhere fully formed but are rather an evolutionary product of a number of factors at work in society. Baskerville in Osoba (2009) suggests that culture can be evaluated by observing and noting values, beliefs, behaviours and symbols over a period of time. Hofstede likewise sought to understand differences in cultural patterns and to understand the mechanisms that enabled those patterns to be stable over time (McGrath Macmillan and Scheinberg. 1992). The initial four value dimensions are initial value dimensions are: large versus small; power distance; strong versus weak; uncertainty avoidance; individualism versus collectivism, and masculinity versus femininity (Hofstede 1998). A fifth dimension was later added following the findings of Bond (1988) from a Chinese Value Survey, namely long- versus short-term orientation.

According to Urban (2006) the five dimensions can be described as:

(i) Power distance relates to the different solutions to the basic problem of human inequality.

(ii) Uncertainty avoidance relates to the level of stress in a society in the face of an unknown future.

(iii) Individualism versus collectivism relates to the integration of individuals into primary groups.

(iv) Masculinity versus femininity relates to the division of emotional roles between men and women. 
(v) Long-term versus short-term orientation relates to the choice of focus for peoples efforts, the future or the present.

In addition to the work by Hofstede (1998), Trompenaars and Hampden-Turner (1993) as well as Urban (2007) analysed culture by the following dimensions: According to Yeganeh, Su, and Sauers (2008) and Williams (2009) Trompenaars and Hampden-Turner's dimensions are described as:

(i) Achievement versus Ascription

(ii) Universalism versus Particularism

(iii) Individualism versus Collectivism

(iv) Neutral versus Affective

(v) Specific versus Diffuse

Hill (1997) illustrates the six determinants of culture: religion, political philosophy, economic philosophy, education, language and social structure. Schwartz (2006) expands "culture" into six features of values:

(i) Values are linked inextricably to effect;

(ii) "Values" refer to desirable goals that motivate action;

(iii) Values transcend specific actions and situations (this feature distinguishes values from narrower concepts like norms and attitudes that usually refer to specific actions, objects or situations);

(iv) Values serve as standards or criteria that guide the selection or evaluation of actions, policies, people and events;

(v) Values are ordered by importance relative to one another to form a system of priorities; and

(vi) The relative importance of values guides action (the trade-offs among relevant competing values is what guides attitudes and behaviours).

Cultural values and practices are the result of a long history of social development (Russell 2005). The study of ethnic entrepreneurship and the importance of social embeddedness can be traced back to the works of Max Weber (1958) and Schumpeter (1934), both of whom argued that the source of entrepreneurial behaviour lay in the social structure of the societies and the value structures they produce (Urban, 2006). Turan and Kara (2007) indicate that entrepreneurship behaviour might be linked to cultural values and suggests that values and beliefs are factors that encourage entrepreneurship within certain cultural groups predisposing their members to entrepreneurship.

Because individuals' personalities and behaviours, firms, political/legal systems, economic conditions, and social background are all intertwined with the national culture from which they originate, the study of entrepreneurship under a cultural umbrella seems appropriate (Lee and Peterson 2000). In a study relating to ethnic entrepreneurship of Indian and Chinese immigrants in the United States of America, Li (2007) concluded that one of the barriers experienced by the Chinese immigrants was the vast differences in culture. The American culture was so different from Chinese culture in many ways which resulted in a challenge for entrepreneurs to become accepted or trusted by native people. In cases of failure the Chinese immigrants felt that their opportunities were limited due to their not having much social and family support in the United States of America. The Chinese entrepreneurs did find advantages in the United States of America in that business failure is not ill thought of in American culture whereas, in Chinese culture, failure is hard to deal with 
since the culture does not encourage risk-taking and failure is looked down upon. The study concluded that culture was less of a perceived barrier among Indians.

In a study relating to cultural values, market institutions and entrepreneurial potential comparing the United States of America, Taiwan and Vietnam, Nguyen, Bryant, Rose, Tseng, and Kapasuwan (2009) concluded that cultural factors appear to have a significant impact on people's desires to create new ventures and that people in a Western culture seem to have higher desires to create new ventures than those of Eastern cultures.

The characteristics and sociological attributes that influence Asian entrepreneurs have been widely researched. Thomas and Mueller (2000) suggests that unlike the idealised American entrepreneur characterised by rugged individualism, there is growing evidence that the Asian entrepreneur relies on familial ties in developing their business. Morris and Schindehutte (2005) - in a study that explored the entrepreneurial values and ethnic enterprise - an examination of six subcultures pointed out that family and clan, hard work, loyalty, duty and relationships tend to be strong values in the Asian cultural context.

Tsui-Auch (2005) points out that Chinese and Indian cultures are characterised by patrilineality, patriarchy and familialism. It is further suggested, given the roots of strong kinship and communal networks, one would expect that ethnic businesses would maintain family management and avoid diversification into areas in which the family members did not have expertise. Abbey (2002) proposed that the cultural background of the entrepreneur plays a significant role in defining the motivation for entrepreneurship.

According to Basu and Altinay (2001) differences in financing a business influences entrepreneurial activity; for example, Islam prohibits usury; therefore one would expect Muslims not to borrow money from banks and would instead rely on savings or family funds. They also suggest that Muslims would not enter businesses that involved alcohol. Additionally, these authors found that Indians who went to East Africa from Gujarat were mainly traders and hence it was not surprising that they engaged in trade enterprises in East Africa.

The list of characteristics and attributes as described in the literature includes:

(i) Network of family and friends that are self-employed

(ii) Choice of trade influenced by parents' background and family tradition

(iii) Type of business influenced by cultural background

(iv) Sources of start-up finance (personal savings, bank loans or family funds)

(v) Longevity of ethnic Indian traders in their specialisations

(vi) Values such as family clan, hard work, loyalty, duty and relationships tend to be strong.

Cultural factors are just one aspect that influences the entrepreneurial process. Another aspect is entrepreneurial orientation, which is defined by Swierczek and $\mathrm{Ha}$ (2003) as a state of mind directing a person's attention towards a goal in order to achieve it. Lumpkin, Cogliser, and Schneider (2009) that successful firms attribute their success to having an "entrepreneurial orientation" approach to decision-making that draws on entrepreneurial skills and capabilities. This is achieved by keeping firms alert by making them aware of marketplace trends, new technologies and helping them evaluate new possibilities.

Lee and Peterson (2000) outline five dimensions of entrepreneurial orientation as consisting of autonomy, innovativeness, risk-taking, proactiveness and competitive aggressiveness, as conveyed by Lumpkin and Dess (1996), and described as: 
(i) Autonomy - the catalyst driving entrepreneurial activity is the independent spirit and freedom necessary to create a new venture. In order for the autonomy dimension to be strong, entrepreneurs must operate within cultures that promote entrepreneurs to act independently, to maintain personal control and to seek opportunities in the absence of societal constraints.

(ii) Innovation - the creative processes of entrepreneurs will determine the strength of the innovativeness dimension of entrepreneurial orientation.

(iii) Risk-taking - the willingness of entrepreneurs to assume risk. Individuals who are willing to accept the uncertainty and riskiness associated with being self-employed as opposed to settling for the refuge of jobs within organisations are often considered entrepreneurs.

(iv) Proactiveness - is crucial to entrepreneurial orientation because it is concerned with the implementation stage of entrepreneurship. Proactive individuals do what is necessary to bring their concepts to fruition and gain an advantage by being the first to capitalise on new opportunities.

(v) Competitiveness Aggressiveness - an important component of entrepreneurial orientation because new ventures are more likely to fail than established businesses. An aggressive stance and intense competition are critical to the survival and success of new start-ups.

Having reviewed the dimensions of culture and its impact on the entrepreneurial process relating to the skills and capabilities of the entrepreneur, the next aspect reviewed is the fit with SMEs and specifically linked to the success factors contributing to entrepreneurial performance in this context. There are several ways in which the success of SMEs can be defined. Lussier and Pfeifer (2001) suggest that small business success can be defined in the simplest terms as the ability to survive or to remain in business. Chivukula, Raman and Ramachandra (2009) suggest that entrepreneurial success be defined using financial and non -financial measures. Financial measures are more widely used to measure success. In a study on the influence of socio - demographic factors on entrepreneurial attributes Chivukula et al. (2009) used growth in total sales and growth in employment as the financial measures in their study and non -financial measures of support received by the entrepreneur, work experience of the entrepreneur and involvement of the entrepreneur in the running of the business. Walker and Brown (2004) suggest that possible non-financial measures could be related to job satisfaction, greater independence, creating opportunities, encouraging new challenges and pursuing one's own interests are more difficult to quantify.

Coy, Shipley and Omer (2007) posits its findings on small business owners in Pakistan revealing that Pakistani business owners believed several factors contributed to their success and listed the following: Working hard for long hours; Product quality; Attention to customer needs; Communication skills and interpersonal skills; Business connections (networking)

\section{Proposition 1: There are no significant differences in managerial functions and business skills between successful and less successful entrepreneurs.}

This was evaluated by determining that there are no significant differences between successful and less successful entrepreneurs on the following variables:

(i) Hours worked per day

(ii) Time spent on financial, marketing, people management and operational issues

(iii) Importance of the following skills in the business: 
(i) Business linkages, industry clusters and networking

(ii) Computer literacy

(iii) Financial management, cash flow, pricing and costing

(iv) Human resource management

(v) Quality management

(vi) Role models (learning from others)

(vii) Good networks with suppliers and understanding customer requirements.

\section{Proposition 2: There are no significant differences in personal factors between successful and less successful entrepreneurs.}

This was evaluated by determining that there are no significant differences between successful and less successful entrepreneurs on the following variables:

(i) Education

(ii) Experience (number of years business existed and number of prior businesses started)

(iii) Entrepreneurial orientation

(iv) Motivational factors

(v) Network of family and friends self-employed

(vi) Involvement of family members in managing the business

(vii) Reliance on family members to help run business

(viii) Following in family tradition in the nature of the business.

\section{Proposition 3: There are no significant differences in financing and ownership of a start-up between successful and less successful entrepreneurs.}

This proposition was evaluated by determining that there are no significant differences between successful and less successful entrepreneurs on the following variables:

(i) How ownership came about

(ii) How the business was financed

(iii) Future plans for business.

A secondary aim of this study is to put forward any key insights from the exploratory study of Indian entrepreneurs that could possibly contribute to entrepreneurial development in South Africa.

\section{METHODOLOGY}

The intention of this research is to explore how the success factors for successful entrepreneurs compare to less successful entrepreneurs of Indian origin. The study sought to answer the following research objectives:

(i) The degree of general management skills employed in the business. 
(ii) The role personal factors such as education, family support, experience, role models, motivation, entrepreneurial characteristics and networking play in start-up and sustaining the business.

(iii) Understand how the business was financed.

The target population for this study is the Indian business community in the SME sector of the Tshwane metropolitan area of South Africa. The research will focus on evaluating Indian entrepreneurs on the following three categories: The degree of general management skills employed in the business; The role personal factors such as education, family support, experience, role models, motivation, entrepreneurial characteristics and networking play in start-up and sustaining the business; Understand how the business was financed.

The unit of analysis was the Indian entrepreneur in the Indian business community involved in the SME sector in the Tshwane metropolitan area. The population of relevance consisted of Indian entrepreneurs in the SME sector. Due to the nature of these populations a specific size cannot be attributed to the population. The research was limited to businesses that complied with the definition of small and medium enterprise as defined by South African legislation in the Small Business Act of 1996, as amended in 2003 (RSA 2006). Two criteria variables were used to classify the data set of respondents into successful and less successful entrepreneurs : namely, growth and turnover. Chivukula, Raman and Ramachandra (2009) used growth in employment as a measure of success; hence growth in the number of employees from when the business was started to the current number of employees was taken to represent growth in the business. The second criterion used was a measure of the annual turnover. It was initially thought that the questionnaire should specifically ask respondents to indicate the business profitability; however, it was decided not to ask this directly. This was because it was anticipated that most respondents would choose not to answer such a question. Therefore respondents were asked to indicate their annual turnover in the form of a range beginning with less than R500,000 to greater than R5 million. For the purpose of this research, the annual turnover of more than R1 million was considered.

A non-probability approach in terms of convenience sampling was used due to the fact that the size of the population was difficult to determine. The research design was quantitative, explorative in nature and a self-administered survey questionnaire was used to gather primary data from respondents.

\section{RESULTS AND DISCUSSION}

\section{Proposition 1: There are no significant differences in managerial functions and business skills between successful and less successful entrepreneurs.}

The statistical significance of the sub-propositions is:

\section{Hours Worked Per Day}

There were no significant differences in the successful and less successful group of entrepreneurs in terms of the number of hours worked per day. A Fisher's Exact test indicated a $p$-value of 0.5408 which is greater than 0.05 . Of the respondents 68 percent indicated that they work between 5 and 10 hours a day, while 28 percent of respondents indicated that they work longer than 10 hours per day. Based on a 6-day working week, respondents of both groups could average about 60 work hours per week. This is in line with Pena (2002) who concluded that entrepreneurs of growing firms are those that spend a large number of hours (that is, 50 to 60 hours) per week on business activities. The result also 
supports the findings by Coy, Shipley and Omer . (2007) who concluded that working hard for long hours was a success factor for Pakistani small business owners.

\section{Time Spent on Managerial Functions}

The time spent on four managerial functions was found to have no significant differences in the successful and less successful group of entrepreneurs in terms of time spent per day on financial issues, marketing, people management and operational issues with a $p$-value greater than 0.05. The Fisher's Exact test $p$-value is provided in Table 1.

Table 1: Significant Differences Relating to Managerial Functions

\begin{tabular}{lc} 
Managerial function variables & $\begin{array}{c}\text { Fisher's Exact Test } \\
\boldsymbol{p} \text {-value }\end{array}$ \\
\hline Financial issues & 0.1186 \\
\hline Marketing & 0.6561 \\
\hline Managing people & 0.4377 \\
\hline Operational issues & 0.6900 \\
\hline
\end{tabular}

The managerial functions of managing a business are seen as important by both groups of entrepreneurs. Of the respondents, 69 percent indicated that they spent more than 3 hours on financial issues in the business, while 82 percent of respondents indicated that they spent more than 3 hours managing operational issues within the business. Of the respondents, 92 percent indicated that they spent more than 3 hours on marketing issues in the business. This is in line with Hill (2001) who cited marketing as a focus area for entrepreneurs.

Of the four categories of managerial functions the least time was spent on managing human resources in the business, both groups indicated that they spent 61 percent on this function. This could be related to the low average of the number of employees within the business. The successful group average is about nine employees while the less successful group is on average three to four employees.

\section{Importance of Business Skills}

There were no significant differences between the successful and less successful group of entrepreneurs in terms of rating the importance of business skills with the $p$-value greater than 0.05. The Fisher's Exact test $p$-value is provided in Table 2.

Table 2: Significant Differences Relating to Business Skills

\begin{tabular}{|c|c|}
\hline Skills variables & $\begin{array}{c}\text { Fisher's Exact Test } \\
p \text {-value }\end{array}$ \\
\hline Business linkages, industry and networking & 0.3680 \\
\hline Computer literacy & 0.9261 \\
\hline $\begin{array}{l}\text { Financial management, cash flow, pricing and } \\
\text { costing }\end{array}$ & 0.3810 \\
\hline Human Resource management & 0.3051 \\
\hline Quality management & 0.2733 \\
\hline Role models (learning from others) & 0.2227 \\
\hline Good networks with suppliers & 0.1582 \\
\hline
\end{tabular}


Over 90 percent of respondents from the successful and less successful group of entrepreneurs rated the above business skills as very or extremely important. This supports the findings of Attahir (1995) who found management skills to be highly ranked by South Pacific small business owners.

\section{Described Market Parameters in Which the Business Operated}

There were no significant differences in the successful and less successful group of entrepreneurs in terms of describing the market in which the business operated. A Fisher's Exact test indicated a $p$-value of 0.5249 which is greater than 0.05 . All respondents could identify the market in which the business operated. However, this does not determine whether respondents had correctly identified or understood the market parameters as described by Attahir (1995) in which the business operated.

\section{Know What Customers Want}

There were no significant differences in the successful and less successful group of entrepreneurs in terms of describing how entrepreneurs stay informed about what customers required. A group $t$-test using the Satterthwaite method indicated a $p$-value greater than 0.05 . The $p$-value is provided in Table 3 .

\begin{tabular}{lcccccc}
\multicolumn{6}{c}{ Table 3: Significant Differences Relating to Know What Customers Want } \\
\hline Variable & Method & Variance & $\begin{array}{c}\text { Degrees } \\
\text { of } \\
\text { freedom }\end{array}$ & t-value & $p$-value \\
\hline $\begin{array}{l}\text { Know what } \\
\text { want }\end{array}$ & customers & Satterthwaite & Unequal & 68 & -0.38 & 0.7055 \\
\hline
\end{tabular}

Both groups of respondents indicated that they strongly agreed with following techniques to understand the customers' needs: Continuously ask them; Put one's self in the customers' shoes; Know what they want; Look at what sales show. This further supports the notion of marketing being a focus area of entrepreneurs.

\section{Acceptance of Proposition 1}

The results of the above significant tests relating to managerial functions and skills are summarised below:

(i) Hours worked per day - accepted

(ii) Time spent on managerial functions per day - accepted

(iii) Importance of business skills - accepted

(iv) Describe the market parameters in which the business operated - accepted

(v) Know what customers want - accepted.

All sub-propositions were accepted, hence proposition 1 is accepted.

\section{Proposition 2: There are no significant differences in personal factors between successful and less successful entrepreneurs.}

The statistical significance of the sub propositions is: 


\section{Education}

There were significant differences in the successful and less successful group of entrepreneurs in terms of education. A Chi-square test indicated a $p$-value that is less than 0.05 . The Chi-square $p$-value is provided in Table 4.

Table 4: Significant Differences Relating to Education

\begin{tabular}{lcccc}
\hline Variable & Method & $\begin{array}{c}\text { Degrees of } \\
\text { freedom }\end{array}$ & Value & $\boldsymbol{p}$-value \\
\hline $\begin{array}{l}\text { Highest level of academic } \\
\text { qualification }\end{array}$ & Chi-square & 68 & 8.1991 & 0.0421 \\
\hline
\end{tabular}

Education levels among the successful group were found to indicate a higher level of formal education (degree and higher) compared with the less successful group, which had a higher level of informal education (matriculation and lower). This finding does not seem to influence the importance of business skills between the two groups which were highly rated. The successful group on average employs more people when compared with the less successful group. This is in line with the 2005 Global Monitor Report on South Africa (von Broemsen et al. 2005) which concludes that the more educated a person, the more likely they are to start a business and the more people they are likely to employ.

\section{Experience}

There were two variables used to describe the entrepreneur's level of experience. The first was the number of years the business existed, and the second was had the entrepreneur started other businesses prior to the current business.

There were significant differences in the successful and less successful group of entrepreneurs in terms of the number of years the business has existed. A group $t$-test using the Satterthwaite method indicated a $p$-value less than 0.05 . The $p$-value is provided in Table 5.

Table 5: Significant Differences Relating to Number of Years Business Existed

\begin{tabular}{llcccc}
\hline Variable & Method & Variance & $\begin{array}{c}\text { Degrees } \\
\text { of } \\
\text { freedom }\end{array}$ & t-value & $\boldsymbol{p}$-value \\
\hline $\begin{array}{l}\text { Number of years the } \\
\text { business existed }\end{array}$ & Satterthwaite & Unequal & 82.7 & 2.02 & 0.0470 \\
\hline
\end{tabular}

The successful group was found to have more experience in terms of running the business due to the fact its business has existed, on average, longer than the less successful group. There were significant differences in the successful and less successful group of entrepreneurs in terms of other businesses started prior to current business. A Chi-square test indicated a $p$-value that is less than 0.05. The Chi-square $p$-value is provided in Table 6 .

Table 6: Significant Differences Relating to Number of Business Start-ups

\begin{tabular}{llccc}
\hline Variable & Method & $\begin{array}{c}\text { Degrees of } \\
\text { freedom }\end{array}$ & Value & $p$-value \\
\hline $\begin{array}{l}\text { Is this the first business } \\
\text { started? }\end{array}$ & Chi-square & 1 & 4.6650 & 0.0308 \\
\hline
\end{tabular}


The successful group indicated that 31 percent of respondents had started a business prior to the current business, compared with 13 percent from the less successful group. This indicates that the successful group had more experience in business start-ups.

\section{Entrepreneurial Orientation}

There were no significant differences in the successful and less successful group of entrepreneurs in terms of describing the entrepreneurial orientation of respondents. A group $t$-test using the Satterthwaite method indicated a $p$-value greater than 0.05 . The $p$-value is provided in Table 7.

Table 7: Significant Differences Relating to Entrepreneurial Orientation

\begin{tabular}{lccccc}
\hline Variable & Method & Variance & $\begin{array}{c}\text { Degrees } \\
\text { of } \\
\text { freedom }\end{array}$ & t-value & $\boldsymbol{p}$-value \\
\hline Personal characteristics & Satterthwaite & Unequal & 76.7 & 1.99 & 0.0502 \\
\hline
\end{tabular}

The findings on entrepreneurial orientation in this study tend to agree with the literature review.

\section{Motivation}

There were no significant differences in the successful and less successful group of entrepreneurs in terms of describing the motivation for starting the business. A group $t$-test using the Satterthwaite method indicated a $p$-value greater than 0.05 . The $p$-value is provided in Table 8.

Table 8: Significant Differences Relating to Motivation

\begin{tabular}{lccccc}
\hline Variable & Method & Variance & $\begin{array}{c}\text { Degrees } \\
\text { of } \\
\text { freedom }\end{array}$ & $\begin{array}{c}\boldsymbol{t} \text { - } \\
\text { value }\end{array}$ & $\boldsymbol{p}$-value \\
\hline Motivational factors & Satterthwaite & Unequal & 76 & 1.74 & 0.0857 \\
\hline
\end{tabular}

The findings on motivational factors for starting a business in this study tend to correlate closely with the defined "pull factors" that cause individuals to become entrepreneurs.

\section{Network of Family and Friends Self-employed}

There were no significant differences in the successful and less successful group of entrepreneurs in terms of having a network of family and friends that are self-employed. A Fisher's Exact test indicated a $p$-value of 0.2560 which is greater than 0.05 . Of the respondents, 97 percent indicated that they have a network of family and friends that are self-employed. This points to a possible extension of the entrepreneurial capacity as well as provides a supply of potential role models to the entrepreneurs of the two groups.

\section{Involvement of Family Members in Managing Business}

There were significant differences in the successful and less successful group of entrepreneurs in terms of the family involvement in the business. A Chi-square test indicated a $p$-value that is less than 0.05 . The Chi-square $p$-value is provided in Table 9. 
Table 9: Significant Differences Relating to Family Involvement in Business

\begin{tabular}{llcccc}
\hline Variable & & Method & $\begin{array}{c}\text { Degrees of } \\
\text { freedom }\end{array}$ & Value & $\boldsymbol{p}$-value \\
\hline $\begin{array}{l}\text { Family involvement } \\
\text { business }\end{array}$ & in & Chi-square & 1 & 8.2053 & 0.0042 \\
\hline
\end{tabular}

The higher tendency of successful entrepreneurs to have family members involved in managing the business may point to the extended family system as defined by Arkin Magyar, K.P. \& Pillay (1989), whereby decision-making is conducted on a joint basis.

\section{Reliance on Family to Run Business}

There were significant differences in the successful and less successful group of entrepreneurs in terms of reliance on family members to help run the business. A Chi-square test indicated a $p$-value that is less than 0.05 . The Chi-square $p$-value is provided in Table 10.

Table 10: Significant Differences Relating to Reliance on Family

\begin{tabular}{lccccc}
\hline Variable & Method & $\begin{array}{c}\text { Degrees of } \\
\text { freedom }\end{array}$ & Value & p-value \\
\hline $\begin{array}{l}\text { Reliance on family } \\
\text { members to run business }\end{array}$ & Chi-square & 2 & 7.9941 & $\mathbf{0 . 0 1 8 4}$ \\
\hline
\end{tabular}

This finding correlates with Thomas and Mueller (2000) who conclude there is growing evidence that the Asian entrepreneur relies on familial ties in developing their business.

\section{Following Family Tradition in the Nature of Business}

There were no significant differences in the successful and less successful group of entrepreneurs in terms of describing the extent to which the current business is similar to the respondents' parent's business. A Chi-square test indicated a $p$-value that is greater than 0.05. The Chi-square $p$-value is provided in Table 11.

Table 11: Significant Differences Relating to Family Tradition of Business

\begin{tabular}{lcccc}
\hline Variable & Method & $\begin{array}{c}\text { Degrees of } \\
\text { freedom }\end{array}$ & Value & $\boldsymbol{p}$-value \\
\hline $\begin{array}{l}\text { Extent to which business is } \\
\text { similar to parents' business }\end{array}$ & Chi-square & 2 & 0.9070 & 0.6354 \\
\hline
\end{tabular}

A higher percentage (66 percent) of the successful group indicated that their parents owned businesses compared with the less successful group (37 percent). This indicates a tendency among the successful group to "follow in their parents' footsteps" when starting a business. However, the majority of both groups indicated that their business was not similar to their parents. Therefore, the findings do not correlate with Tsui-Auch (2005) who concluded that ethnic businesses would maintain family management and avoid diversification into areas in which the family members did not have expertise.

\section{Rejection of Proposition 2}

The results of the above significant tests relating to personal factors are summarised below: 
(i) Education - rejected

(ii) Number of years business existed - rejected

(iii) Number of prior businesses started - rejected

(iv) Entrepreneurial orientation - accepted

(v) Motivational factors - accepted

(vi) Network of family and friends self-employed - accepted

(vii) Involvement of family members in managing business - rejected

(viii) Reliance on family members to help run business - rejected

(ix) Following in family tradition in nature of business - accepted.

Not all sub-propositions were accepted, therefore proposition 2 is rejected.

\section{Proposition 3: There are no significant differences in financing and ownership of a start-up between successful and less successful entrepreneurs.}

The statistical significance of the sub-propositions is:

\section{How Ownership of Business Came About}

There were no significant differences in the successful and less successful group of entrepreneurs in terms of how ownership of the current business came about. A Chi-square test indicated a $p$-value that is greater than 0.05 . The Chi-square $p$-value is provided in Table 12.

Table 12: Significant Differences Relating to How Ownership Came About

\begin{tabular}{lccccc}
\hline Variable & Method & $\begin{array}{c}\text { Degrees of } \\
\text { freedom }\end{array}$ & Value & $\boldsymbol{p}$-value \\
\hline $\begin{array}{l}\text { How did ownership } \\
\text { business come about }\end{array}$ & Chi-square & 2 & 2.1054 & 0.3490 \\
\hline
\end{tabular}

In terms of ownership, the successful group indicated the majority founded the business followed by equal representation of inheritance and purchase of the business. The less successful group indicated the majority founded the business followed by purchase and then inheritance. Inheritance in the less successful group was 9 percent lower than the successful group. The higher incidence of inheritance of business in the successful group could be a direct consequence of the extended family concept described in the literature.

\section{Sourcing of Capital to Finance Business}

There were no significant differences in the successful and less successful group of entrepreneurs in terms of the sources of capital used to fund the start-up of the business. A Fisher's Exact test indicated a $p$-value of 0.3058 which is greater than 0.05 . The sources of finance are in line with the literature; both groups of entrepreneurs favoured own capital, followed by commercial capital and lastly family capital. None of the respondents looked to friends to help finance the business.

\section{Future Plans for the Business}

There were no significant differences in the successful and less successful group of entrepreneurs in terms of describing the future plans for the business. A group $t$-test using 
the Satterthwaite method indicated a $p$-value greater than 0.05 . The $p$-value is provided in Table 13.

Table 13: Significant Differences Relating to Motivation

\begin{tabular}{llccccc}
\hline Variable & Method & Variance & $\begin{array}{c}\text { Degrees } \\
\text { of } \\
\text { freedom }\end{array}$ & $\begin{array}{c}t \text {-valu } \\
\mathbf{e}\end{array}$ & $\begin{array}{c}\boldsymbol{p} \text {-valu } \\
\mathbf{e}\end{array}$ \\
\hline $\begin{array}{l}\text { Future plans for the } \\
\text { business }\end{array}$ & Satterthwaite & Unequal & 775.2 & 0.66 & 0.5104 \\
\hline
\end{tabular}

Respondents from both groups indicated a growth-orientated strategy towards their vision for the business. This is in line with the six dimensions of entrepreneurial orientation cited by Hills and La Forge (1992).

\section{Acceptance of Proposition 3}

The results of the above significant tests relating to financing and ownership of business are summarised below:

(i) How ownership of business came about - accepted

(ii) Sourcing of capital to finance business - accepted

(iii) Future vision for the business - accepted.

All the sub-propositions were accepted, therefore proposition 3 is accepted.

\section{CONCLUSION}

This study was undertaken to explore the factors that differentiate successful and less successful Indian entrepreneurs in a South African context. It outlined a process of how to go about comparing the success factors of successful and less successful ethnic entrepreneurs. The objectives of this study were achieved.

The aim of this research was to explore the degree to which the sample group could identify and relate to general management and personal factors and their approach to financing the start-up. Further the objective was to explore how the factors and approach differed across successful and less successful entrepreneurs. Inferential analysis was used to compare the two groups. The research concluded that there are not significant differences in terms of managerial functions and the importance of these skills in operating a business. Both groups of entrepreneurs, the successful and less successful, deemed these factors equally important.

There were some significant differences between the comparable groups relating to personal factors that characterise the entrepreneurial approach. These differences relate to the variables of education, length of time the business existed, the number of previous businesses started and the involvement and reliance of family members in managing and running the business. This relates to the literature, which concludes that the Asian entrepreneur is characterised by the extended family concept, and family affairs are concluded on a joint basis. This suggests a bigger involvement of family which aids entrepreneurs to be more successful. The variables that indicated no significant difference relate to entrepreneurial orientation, motivational factors, network of family and friends that are self-employed, and following in family tradition in terms of type of business. There were also no differences in the way business was financed if the owner founded the business. Neither of the groups seems to have an advantage in terms of financing the business. This 
study contributes to the domain of entrepreneurship within the selected research frame as follows: Family support in running the business, as well as in managing the business, is more important to the respondents of the successful group. The findings of this study align to the characteristics and attributes of Asian entrepreneurs as found in literature; Customer awareness is critical to both successful and less successful entrepreneurs in this frame; Respondents favourably rated that they would consider acquiring other businesses in the industry, thus indicating an element of organic growth; The length of time the businesses in this study have existed points to a success rate in excess of the typical seven years and thus indicates most of the businesses in this study are sustainable.

Further research objectives that should be considered are: Draw comparisons across cultural groups within South Africa in terms of Greek or Portuguese business communities as well as other emerging markets; Understand how skills transfer in relation to running a business takes place within the Indian community; Draw comparisons between Indian business owners across different geographical hubs within South Africa as well as internationally such as in India; Understand the business models employed by Indian entrepreneurs on a global level; Understand what formal education Indian entrepreneurs undertake and determine whether this is used in a business context.

\section{REFERENCES}

Abbey, A., 2002. "Cross Cultural Comparision of the Motivation for Entrepreneurship." Journal of Business and Entrepreneurship 14(1):69-81.

Aldrich, H., C. Zimmer, and E. McEvoy, 1989. "Continuities in the Study of Ecological Succession: Asian Businesses in Three English Cities." Social Forces 67:920-944.

Attahir, Y. (1995). Critical success factors for small business perceptions of South Pacific enterprises. Journal of Small Business Management, 68-73.

Arkin, A.J., Magyar, K.P. \& Pillay, G.J. (Eds.) (1989). The Indian South African: A contemporary profile. Owen Burgess: Pinetown, South Africa

Baskerville, R. F., 2003. "Hofstede Never Studied Culture." Accounting, Organisations and Society 28(1):1-14.

Basu, A., and E. Altinay, 2001. "The Interaction Between Culture and Entrpreneurship in London's Immigrant Businesses." International Small Business Journal 20(4):371393. doi: 10.1177/0266242602204001.

Bond, M.H., 1988. "Finding universal dimensions of individual variation in multicultural studies of values: The Rokeach and Chinese value surveys". Journal of Personality and Social Psychology, Vol 55(6), Dec 1988, 1009-1015

Chaudhry, S., and D. Crick, 2008. "An Exploratory Investigation into the Practices of Leading Asian Entrepreneurs in the UK." Journal of Small Business and Entrepreneurship 21(3):309-324.

Chivukula, V.R., Raman, K.J. \& Ramachandra, A. A. (2009). Influence of sociodemographic factors on entrepreneurial attributes and success. South Asian Journal of Management, 16(4), 111-126.

Chrisma, J. J., J. H. Chua, and L. P. Steier, 2002. "The Influence of National Culture and Family Involvement on Entrepreneurial Perceptions and Performance at the State Level." Entrepreneurship Theory and Practice 26(3):67-80. 
Coy, P.S., Shipley, M.F. \& Omer, K. (2007). Factors contributory to success: A study of Pakistan's small business owners. Journal of Development Entrepreneurship, 12(2) 181-198.

Granato, J., R. Ingehart, and D. Leblang, 1996. "The Effect of Cultural Values on Economic Development: Theory, Hypotheses and Some Emprical Tests. American Journal of Political Science (40):607-631.

Henderson, J. R., 2002. "Building the Rural Economy with High-growth Entrepreneurs." Economic Review Federal Reserve Bank of Kansas, second quarter. Kansas City. (On-line). Available:

http://www.kansascityfed.org/PUBLICAT/ECONREV/PDF/3q02hend.pdf.

Herrington, M., J. Kew, and P. Kew, 2008. "Global Entrepreneurship Monitor :The South African Report 2008". Cape Town: The UCT Centre for Innovation and Entrepreneurship, University of Cape Town.

Hill, C. W. L., 1997. International Business: Competing in the Global Marketplace. Chicago: Irwin.

Hill, J. (2001). A multidimensional study of the key determinants of effective SME marketing activity: Part 1. International Journal of Entrepreneurial Behaviour and Research, 5(7) 171-204.

Hills, G.E. \& La Forge, R.W. (1992). Research at the marketing interface to advance theory. Entrepreneurship Theory and Practice, 14(1), 7-26.

Hofstede, G., 1998. "Attitudes, Values and Organisational Culture: Disentangling the Concepts." Organisational Studies 19(3):477-493.

Hofstede, G. H. (2001). Culture's consequences, (2nd ed.) Thousand Oaks, CA: Sage

Li, W., 2007. "Ethnic Entrepreneurship: Studying Chinese and Indian Students in the United States." Journal of Developmental Entrepreneurship 12(4):449-466.

Lumpkin, G. T., and G. G. Dess, 1996. "Clarifying the Entrepreneurial Orientation Construct and Linking it to Performance." Academy of Management Review 21:135-172.

Lumpkin, G. T., C. C. Cogliser, and D. R. Schneider, 2009. "Understanding and Measuring Autonomy: An Entrepreneurial Orientation Perspective." Entrepreneurship Theory and Practice 33(1):47-69. doi: 10.1111/j.1540-6520.2008.00280-x.

Lussier, R. \& Pfeifer, S. (2001). A cross-national prediction model for business success. Journal of Small Business Management, 39(3) 228-237.

Masurel, E., and P. Nijkamp, 2003. "Differences between First-generation and SecondGeneration Ethnic Start-ups: Implication for a New Support Policy." Faculty of Economics and Business Administration. Amsterdam: Free University.

McGrath, R. G., I. C. MacMillan, and S. Scheinberg, 1992. "Elitists, Risk Takers and Rugged Individualists? An Exploratory Analysis of Cultural Differences between Entrepreneurs and Non Entrepreneurs." Journal of Business Venturing 7(2):115-135.

Minniti, M., and M. Lévesque, 2010. "Entrepreneurial Types and Economic Growth." Journal of Business Venturing 25(3):305-314.

Morris, M., and M. Schindehutte, 2005. "Entrepreneurial Values and the Ethinic Enterprise: An Examination of Six Subcultures." Journal of Small Business Management 43(4):453-479. 
Nguyen, T. V., S. E. Bryant, J. Rose, C. H. Tseng, and S. Kapasuwan, 2009. "Cultural Values, Market Institutions and Entrepreneurship Potential. A Comparative Study of the United States, Taiwan and Vietnam." Journal of Developmental Entrepreneurship 14(1):21-37.

Osoba, B. J., 2009. "Cultural and Entrepreneurial Activity in the United States: A Quantitative Analysis." The European Journal of Social Science Research 22(3):341-370.

Pena, I. (2002). Intellectual capital and business start-up success. Journal of Intellectual Capital, 3(2), 180-198.

RSA (Republic of South Africa). (2003). "National Small Business Amendment Act. Act 26 of 2003." Government Gazette 19 (25763). Pretoria: Government Printer.

Russell, R., 2005. "Cultural Influences on Entrepreneurship: Implications for the Emergence of New Ventures in Latin America." Journal of Transnational Management 10(1):3759.

Schumpeter, J. A., 1934. The Theory of Economic Development. Cambridge: Harvard Press.

Schwartz, S., 2006. "A Theory of Cultural Value Orientations: Explication and Applications." Comparative Sociology 5(3):137-182.

Swierczek, F. W., and T. T. Ha, 2003. "Motivation, Entrepreneurship and the Performance of SMEs in Vietnam." Journal of Enterprising Culture 11(3):47-68.

Thomas, A. S., and S. L. Mueller, 2000. "A Case for Comparative Entrepreneurship: Accessing the Relevance of Culture." Journal of International Business Studies 31(2):287-301.

Trompenaar F. 1993. Riding the Waves of Culture: Understanding Culture and Diversity in Business. London: Economist Books.

Trompenaars, F., and C. Hampden-Turner, 1998. Riding the Waves of Culture: Understanding Diversity in Global Business. Second edition. New York: McGraw-Hill.

Tsui-Auch, L., 2005. "Unpacking Regional Ethnicity and the Strength of Ties in Shaping Ethnic Entrepreneurship." Organisation Studies 26(8):1189-1216.

Turan, M., and A. Kara, 2007. "An Exploratory Study of Characteristics and Attributes of Turkish Entrepreneurs: A Cross-Country Comparision to Irish Entrepreneurs." International Journal of Entrepreneurship 5:25-46.

Ucbasaran, D., W. Wright, and P. Westhead, 2003. "A Longitudinal Study of Habitual Entrepreneurs: Starters and Acquirers." Entrepreneurship and Regional Development 15(3):207-228.

Urban, B., 2006. "Entrepreneurship in the Rainbow Nation: Effect of Cultural Values and ESE on Intentions." Journal of Developmental Entrepreneurship 11(3):171-186.

Urban, B., 2007. "A Framework for Understanding the Role of Culture in Entrepreneurship." Acta Commercii 7:82-95.

Von Broembsen, M., E. Wood, and M. Herrington, 2005. "Global Entrepreneurship Monitor: South African Report 2005". Cape Town: The UCT Centre for Innovation and Entrepreneurship, University of Cape Town.

Waldinger R, Aldrich H, and Ward B. 1990. Ethic entrepreneurs: Immigrant business in industrial societies. Sage series on Ethnic relations, Volume 1. Sage Publications, London 
Waldinger, R., 1989. "Structural Opportunity or Ethnic Advantage? Immigrant Business Development in New York." International Migration Review 23:48-72.

Waldinger, R., H. Aldrich, and R. Ward, 1990. "Ethnic Entrepreneurs: Immigrant Business in Industrial Societies". Sage Series on Race and Ethnic Relations, Vol. 1. London: Sage.

Walker, E. and Brown, A. (2004). What success factors are important to small business owners? International Small Business Journal, 22 (6) 577-594.

Weber, M., 1956. The Protestant Ethic and the Spirit of Capitalism. London: Allen \& Unwin.

Wickham P. 2006. Strategic entrepreneurship. Fourth edition. Pearson Education, Harlow England.

Williams, C., 2009. Cultural Differences between South Africa, Onshore Indian and Offshore Indian IT Teams. Unpublished Master of Business Administration dissertation. Johannesburg: Gordon Institute of Business Science.

Yeganeh, H., Z. Su, and D. Sauers, 2008. "The Applicability of Widely Employed Frameworks in Cross-Cultural Management Research." Proceedings of the 2008 Academy of International Business Conference, Milan.

Zikmund, W. G., 2003. Business Research Methods (7th edition). Ohio: Cengage Learning South-Western Publishers. 